\title{
Grazing behaviour of free-ranging donkeys and Shetland ponies in different reproductive states
}

\begin{abstract}
We investigated how free-ranging mares of two species of equids (donkeys and Shetland ponies) modify their foraging behaviour to meet the increased nutritional requirements induced by lactation. We initially hypothesised that lactating mares would graze for a longer time and/ or graze faster than non-lactating (dry) mares. The grazing behaviour of free-ranging animals, foraging in two lowproductive dune areas, was recorded during 1 year. Results show that in both species lactating animals did not spend more time grazing than non-lactating mares. However, lactating animals took more bites, and therefore achieved a higher bite rate than dry mares. Several factors affected the differences between lactating and non-lactating animals. Lactating mares took more bites only in grassy and rough vegetations and they did this only in patches with a short sward height. In addition, lactating mares took more bites of grasses only and not of forbs or woody plants. We conclude that the extra grazing effort of the lactating animals was not distributed randomly. Lactating mares invested their extra grazing effort principally towards those items that are the most grazed by the equids in general. We propose some hypotheses to explain why lactating mares increase their bite rate instead of augmenting the time spent grazing.
\end{abstract}

Key words Lactation $\cdot$ Equids $\cdot$ Horses $\cdot$ Grazing time $\cdot$ Bite

\section{Introduction}

The nutritional requirements of horses are influenced by a large number of factors such as body size, age, condition,

I. Lamoot $(\bowtie) \cdot$ C. Vandenberghe $\cdot$ M. Hoffmann

Department of Biology, Terrestrial Ecology Unit, Ghent University, Krijgslaan 281-S8, 9000 Ghent, Belgium

Tel. +32-2-5581822; Fax +32-2-5581805

e-mail: Indra.Lamoot@instnat.be

I. Lamoot $\cdot$ D. Bauwens $\cdot$ M. Hoffmann

Institute of Nature Conservation, Kliniekstraat 25, 1070 Brussels,

Belgium health, and reproductive state (Pilliner 1999). The effect of reproduction on energy requirements varies with reproductive state. During the first 8 months of gestation, requirements for mares do not differ from those for maintenance. Energy requirements increase steadily during the last trimester of gestation, when they reach values that are $20 \%$ above maintenance levels. The protein requirements increase to $32 \%$ above maintenance levels, and there are high demands for calcium and phosphorus (data for $200-\mathrm{kg}$ mares; NRC 1989). Lactation is nutritionally far more demanding for the mare than gestation. Although there is no agreement about the influence of the mare's intake on the foal's growth (Doreau and Boulot 1989), it is generally accepted that the production of milk poses high nutritional demands on the lactating mares, especially during the first 3 months of the lactation period (NRC 1989), when the amount of digestible energy and crude protein in the diet surpass with 86 and $132 \%$, respectively, the demands for maintenance. As lactation progresses the demands decrease but stay higher than the maintenance requirements. In addition, the needs for calcium and phosphorus by lactating mares are more than double those for non-lactating mares (NRC 1989).

It can be expected that free-ranging lactating horses modify their foraging behaviour to meet the increased nutritional requirements. Thus, lactating mares may graze for longer periods of time, graze faster, take bigger bites, or may select a higher quality diet. Surprisingly, these issues have been considered only very rarely and often superficially in horses (Duncan 1980, 1985; Rittenhouse 1986; Canacoo and Avornyo 1998; Moehlman et al. 1998; Vulink 2001; Ruckstuhl and Neuhaus 2002; see Discussion), although more detailed studies were done with ruminants (e.g. Parsons et al. 1994; Penning et al. 1995; Gibb et al. 1999). We present results of a preliminary study that explored differences in grazing behaviour between lactating and non-lactating free-ranging equids. Our study subjects were two species of small equids, Shetland ponies (Equus caballus) and donkeys (Equus asinus), which were grazing in dune habitats. We predicted that lactating animals would achieve a greater energy intake by grazing longer and/or 
biting faster, and hence take more bites than non-lactating mares. Free-ranging animals have to make many foraging decisions at different levels (Senft et al.1987). These are not only influenced by changes in the animal's needs, but also by factors such as forage availability and quality, which are in turn determined by environmental conditions. Previous studies reported the influence of seasonality and vegetation features on the grazing behaviour of free-ranging equids in temperate regions (Putman et al. 1981; Pratt et al. 1986; Gordon 1989; Duncan 1983, 1992; Cosyns et al. 2001; Menard et al. 2002). In general, free-ranging equids show a decreased grazing activity in summer compared to winter. Although they forage preferably in grasslands year-round, they increase foraging activity in scrub and woodland during autumn and winter. Therefore, putative differences in grazing behaviour between lactating and non-lactating mares might be affected by seasonality and vegetation characteristics. Consequently we include in our analyses the possible effects of season and vegetation characteristics (composition and height) on grazing behaviour.

\section{Study area}

We performed our study at two nature reserves ("Houtsaegerduinen" and "Westhoek") located in the coastal dune area of Belgium, Europe. In both areas domesticated grazers were introduced as a nature management tool. Both reserves are located in a coastal region with mild winters and mild summers. Mean annual temperature is $9.8^{\circ} \mathrm{C}$. In summer, autumn, winter, and spring, the mean temperature is $15.9,10.8,3.9$, and $8.7^{\circ} \mathrm{C}$, respectively; mean monthly precipitation is $60.7,74.8,56.5$, and $48.5 \mathrm{~mm}$, respectively (means over the period 1963-2002; Meteo WVL 2003).

In the "Houtsaegerduinen" a herd of donkeys (E. asinus) graze throughout the entire area of the reserve (total area 80 ha). This site is mainly occupied by Hippophae rhamnoides/Ligustrum vulgare scrub, with relatively small and scattered patches of dune grassland and grey dune (Cladonio-Koelerietalia). Old, deteriorating Hippophae scrub is generally replaced by species-poor grassland dominated by Calamagrostis epigejos. Part of the area has been planted with Alnus glutinosa and several non-native tree species (Populus div. spp.). For drinking the donkeys have access to two water pools, located more or less centrally in the reserve.

The "Westhoek" reserve (total area 340 ha) offers a diverse landscape consisting of a fore dune ridge and two dune slack zones that are separated by a large mobile dune. A herd of Shetland ponies (E. caballus) grazes in a fenced area (ca. 60 ha) encompassing a dune slack zone and an inner dune ridge. More or less closed vegetation covers twothirds of this area: main shrub species are H. rhamnoides, L. vulgare, Crataegus monogyna, and Sambucus nigra; tree species are Populus $x$ canadensis, P. canescens, Ulmus minor, and A. glutinosa. The other third of the fenced area is occupied by grasslands and herbaceous vegetations: species-rich dune grasslands; tall herb vegetation with Cirsium arvense, Eupatorium cannabinum, Lysimachia vulgaris, Lythrum salicaria, or Iris pseudacorus; patches of speciespoor grassland enclosed by scrub, dominated by Calamagrostis epigejos; grey dune and some marram dune (Ammophila arenaria) vegetation. The ponies have access to several water pools to drink.

\section{Materials and methods}

Animals

In both areas grazing started in April 1997. When field observations for the present study started during summer 2000, 15 donkeys (one adult stallion, one stallion of 2 years, one male yearling, five adult mares, two mares of 2 years, two female yearlings, and three male foals) were present in "Houtsaegerduinen" and 19 ponies (one adult stallion, three stallions of 2 years, one male yearling, eight adult mares, two mares of 2 years, two female yearlings and two male foals) and four Highland cattle were grazing in "Westhoek". In both study areas, the animals are free ranging, graze year-round, and get no additional food.

In "Houtsaegerduinen" two donkey mares that foaled in June 2000 were chosen as the focal lactating animals. During the observation period these females were also pregnant, as they both foaled again in July 2001. Two adult mares that never foaled were chosen as the non-lactating, non-pregnant (hereafter called "dry") mares. Body weight of the four donkey mares was taken in May 2000 and again in March 2001. The two lactating mares weighed 168.5 and $176.5 \mathrm{~kg}$ in 2000 and 143.5 and $162.5 \mathrm{~kg}$ in 2001, respectively; the non-lactating mares weighed 187.5 and $181.5 \mathrm{~kg}$ in 2000 and 178 and $180.5 \mathrm{~kg}$ in 2001 , respectively.

In "Westhoek" there were only two lactating pony mares present in 2000; their foals were born in March and April 2000. Both were pregnant again and foaled in April 2001. Because all adult and 2-year-old females were pregnant, we choose the two yearling females as the non-lactating, nonpregnant mares. There are no data available of the body weights of the focal animals. Weaning of all the donkey and pony foals occurred naturally, so the mares nursed their foals until a few months before the next foals were born.

\section{Behavioural observations}

Data were collected through continuous focal animal observation (Altmann 1974). From August 2000 to July 2001 we conducted 39 and 35 sessions of $6 \mathrm{~h}$ of continuous observation at "Houtsaegerduinen" and "Westhoek", respectively (three or four sessions per month; two observers were involved in the data collection). For practical reasons all observations took place during daylight (between 06.00 and 19.00 hours). Before the start of each session we chose at random a lactating and a dry individual from those selected for this study. We then continuously monitored the behaviour of one focal animal during a 1-h period and then 
switched to the other animal. This was repeated three times, such that each observation session covered six 1-h periods. If the two focal animals were not grazing in the neighbourhood of each other, we observed the same animal during three successive hours and subsequently located the other individual and observed it during the following $3 \mathrm{~h}$. Most of the animals in both study areas are habituated to the presence of humans and can be approached closely (1 m) without appreciably influencing their behaviour.

We recorded the start and end time (accuracy: $1 \mathrm{~s}$ ) of the observed behaviours, as well as vegetation type and sward height, on a protocol form. Behavioural acts recorded were grazing, drinking, walking, standing alert, resting upright, laying down, rolling, grooming, mutual grooming, nursing, defecating, urinating, sniffing, scratching with hoof in soil, aggression, interactive behaviour, flehming, and sexual activity. For the present study we only considered the grazing behaviour. Additionally, while a horse was grazing, we recorded plant species eaten and the number of bites taken (using a mechanical counter, four digits).

The different vegetation types distinguished in the field $(n=18)$ were grouped into five habitat types: "grassy vegetation", "grass with shrub invasion", "rough vegetation", "scrub", and "woodland". For sward height we used a scale related to the animal's physiognomy: "no height" (in case of no vegetation), "closely grazed", "hoof", "knee", "belly", "spine", and "higher". All plant species eaten were grouped into four forage classes: "grasses" (grasses in the strict sense, sedges and rushes), "forbs", "woody plants", and "other" (e.g. mosses and ferns, unidentified plant species, soil). Season definition follows the plant productivity periods in temperate regions, that is, summer (June-August), autumn (September-November), winter (December-February), and spring (March-May).

\section{Data analysis}

\section{Grazing behaviour}

We analysed data for donkeys and ponies separately. Interspecific differences could not be investigated at a quantitative level, since the two equid species forage in different areas.

We quantified aspects of grazing behaviour of the equids with the variables "grazing time", "number of bites", and "bite rate" (i.e. number of bites/minute grazing) and calculated their average value for combinations of lactation state and habitat type (or height category or forage class) per day (i.e. 3-h observation period). Because the animals were grazing mostly in patches where a mix of forage classes (e.g. grasses and forbs) were available, it was impossible to record the time that an animal was grazing a specific plant class. Therefore, we could not estimate grazing time and bite rate per forage class.

To calculate mean grazing time and number of bites, we included zero values. Thus, when on a given day an animal did not graze in a given habitat type (or height category or forage class), grazing time and number of bites were set to zero. This is appropriate because we assume that an animal can potentially graze in all habitat types (or height categories or forage classes) within a single observation period. Bite rate is dependent on the variables "number of bites" and "grazing time". However, we wanted to consider this third variable, and obtain additional information, by working with "effective" bite rate in a habitat type or height category. Therefore, we did not include zero values for calculating mean bite rate, and so we considered this variable only when the horses were actually grazing in that habitat type or height category.

\section{Statistics}

We used mixed-model analysis of variance (ANOVA) to investigate the effects of the fixed factors Lactation State, Habitat Type, Sward Height, Season, and Forage Class (only for number of bites) and their interactions, on the variation in grazing time, number of bites, and bite rate. A repeated statement was used to take into account that the individual animals were sampled more than once. Because differences in grazing behaviour may exist between individual animals, we initially included a random factor with Individual as subject in our ANOVA model. If the random factor was not significant, we excluded it from the final model. Similarly we eliminated non-significant interactions of the fixed effects from our ANOVA model.

Our data often did not meet the main assumptions of ANOVA (i.e. normality of distributions and homogeneity of variances), mainly because we included zero values and simultaneously considered various factors. Unfortunately, there is no non-parametric alternative for ANOVA that satisfactorily deals with interactions between fixed factors on the one hand, and random factors on the other. Hence, we relied on the robustness of ANOVA when its assumptions are violated (Neter et al. 1996, pp. 776-777) and were cautious in interpreting the results, especially when significance values approached $P=0.05$.

Analyses were performed using SAS System V8. Number of degrees of freedom was estimated by the Satterthwaite method.

\section{Results}

Grazing behaviour in all habitat types

The time spent grazing by donkeys was significantly influenced by the factors Habitat Type and Season, and by their interaction effect. Although Lactation State did not significantly affect grazing time, the effect of the interaction between Lactation State and Habitat Type was significant (Table 1). Figure 1 shows that lactating mares spent more time grazing in grassy habitats than dry mares, but no differences were apparent in the other habitat types.

The number of bites taken per $3 \mathrm{~h}$ by grazing donkeys was significantly influenced by Lactation State, Habitat 
Table 1. Results of the analysis of variance (ANOVA) model examining the effects of the factors Lactation State, Habitat Type, and Season on the variables grazing time, number of bites, and bite rate for donkeys and ponies. Shown are the final models after elimination of non-significant three-way and two-way interactions

\begin{tabular}{|c|c|c|c|c|c|c|c|c|c|c|}
\hline & \multirow[t]{2}{*}{$d f_{1}$} & \multicolumn{3}{|c|}{ Grazing time } & \multicolumn{3}{|c|}{ Number of bites } & \multicolumn{3}{|c|}{ Bite rate } \\
\hline & & $d f_{2}$ & $F$ & $P$ & $d f_{2}$ & $F$ & $P$ & $d f_{2}$ & $F$ & $P$ \\
\hline \multicolumn{11}{|l|}{ Donkeys } \\
\hline Lactation & 1 & 155 & 1.44 & 0.232 & 139 & 11.05 & 0.001 & 228 & 11.79 & $<0.001$ \\
\hline Habitat & 4 & 245 & 13.52 & $<0.001$ & 235 & 19.50 & $<0.001$ & 228 & 10.04 & $<0.001$ \\
\hline Season & 3 & 167 & 3.79 & 0.012 & 152 & 1.62 & 0.187 & 228 & 6.52 & $<0.001$ \\
\hline Habitat $\times$ Season & 12 & 257 & 3.32 & $<0.001$ & 240 & 2.93 & $<0.001$ & & & \\
\hline Lactation $\times$ Habitat & 4 & 245 & 2.51 & 0.042 & 233 & 6.17 & $<0.001$ & & & \\
\hline Lactation $\times$ Season & 3 & & & & & & & & & \\
\hline Lactation $\times$ Habitat $\times$ Season & 12 & & & & & & & & & \\
\hline \multicolumn{11}{|l|}{ Ponies } \\
\hline Lactation & 1 & 121 & 0.27 & 0.607 & 305 & 10.89 & 0.001 & 10.7 & 25.07 & $<0.001$ \\
\hline Habitat & 4 & 223 & 68.62 & $<0.001$ & 305 & 72.70 & $<0.001$ & 162 & 16.41 & $<0.001$ \\
\hline Season & 3 & 132 & 1.49 & 0.221 & 305 & 0.27 & 0.844 & 10.6 & 3.97 & 0.039 \\
\hline Habitat $\times$ Season & 12 & 226 & 7.19 & $<0.001$ & 305 & 5.39 & $<0.001$ & & & \\
\hline Lactation $\times$ Habitat & 4 & 222 & 2.77 & 0.028 & 305 & 7.93 & $<0.001$ & & & \\
\hline Lactation $\times$ Season & 3 & & & & & & & & & \\
\hline Lactation $\times$ Habitat $\times$ Season & 12 & & & & & & & & & \\
\hline
\end{tabular}
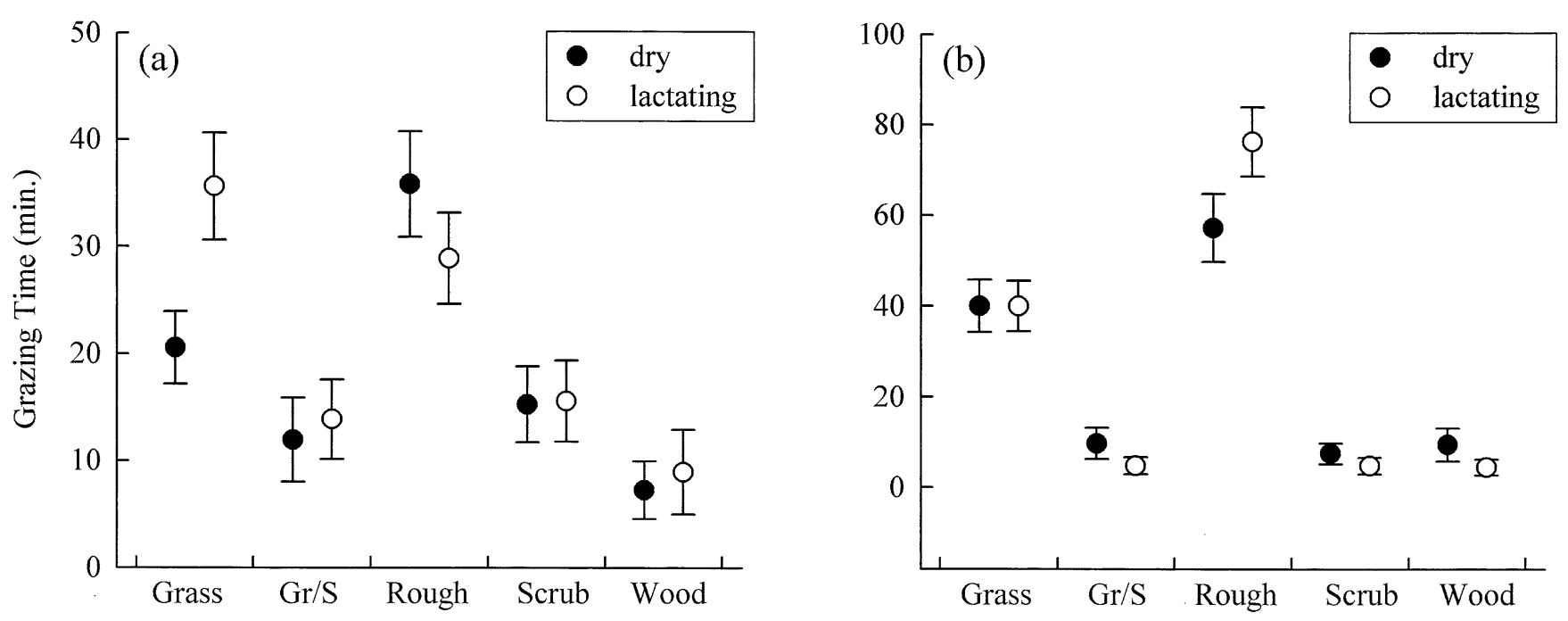

Fig. 1. Mean ( \pm 1 SE) grazing time by lactating (open symbols) and dry (solid symbols) animals in distinct habitat types for donkeys (a) and ponies (b). Habitat types: Grass grassy, Gr/S grass/shrub, Rough rough vegetation, Scrub, Wood woodland. Note that the $y$-axes of the two panels have different scales

Type, and by the interaction effects between Lactation State and Habitat and between Habitat and Season (Table 1). Overall, lactating donkeys took more bites than dry mares (Table 2). However, the significant effect of the interaction between Lactation State and Habitat Type indicates that this difference varied among habitat types and was indeed only pronounced in grassy vegetation (Fig. 2).

The bite rate of grazing donkeys was significantly influenced by Lactation State, Habitat Type, and Season, but not by the interaction effects between these factors (Table 1 ). Lactating mares exhibited a higher bite rate than dry mares (Table 2).

For the ponies, grazing time was significantly affected by Habitat Type, the interaction between Habitat Type and
Season, and between Lactation State and Habitat Type, although there was no significant effect of Lactation State on grazing time (Table 1). Lactating pony mares spent more grazing time than dry mares in rough vegetation only (Fig. 1).

Lactation State, Habitat Type, the interaction between Lactation and Season and between Lactation and Habitat had significant effects on the number of bites taken by ponies (Table 1). Lactating ponies took more bites than dry mares (Table 2), but this difference was only apparent in rough vegetation (Fig. 2).

Bite rate by the ponies was significantly affected by the interaction between Lactation State and Season, and by the factors Lactation State, Season, and Habitat Type (Table 1). 
Table 2. Grazing behaviour of dry and lactating donkeys and ponies. Null values are included for the calculation of mean grazing time and mean number of bites (per $3 \mathrm{~h}$ )

\begin{tabular}{|c|c|c|c|c|c|c|c|c|c|}
\hline & \multicolumn{3}{|c|}{ Grazing time (min) } & \multicolumn{3}{|c|}{ Number of bites } & \multicolumn{3}{|c|}{ Bite rate (bites/min grazing) } \\
\hline & Mean & SE & $n$ & Mean & SE & $n$ & Mean & SE & $n$ \\
\hline \multicolumn{10}{|l|}{ Donkeys } \\
\hline Dry & 90.87 & 5.54 & 39 & 797 & 70 & 37 & 8.68 & 0.44 & 37 \\
\hline Lactating & 102.95 & 5.78 & 39 & 1250 & 100 & 37 & 12.22 & 0.86 & 37 \\
\hline \multicolumn{10}{|l|}{ Ponies } \\
\hline Dry & 123.85 & 4.74 & 35 & 2340 & 151 & 33 & 18.88 & 1.06 & 33 \\
\hline Lactating & 130.19 & 4.07 & 35 & 3559 & 184 & 33 & 27.66 & 1.27 & 33 \\
\hline
\end{tabular}
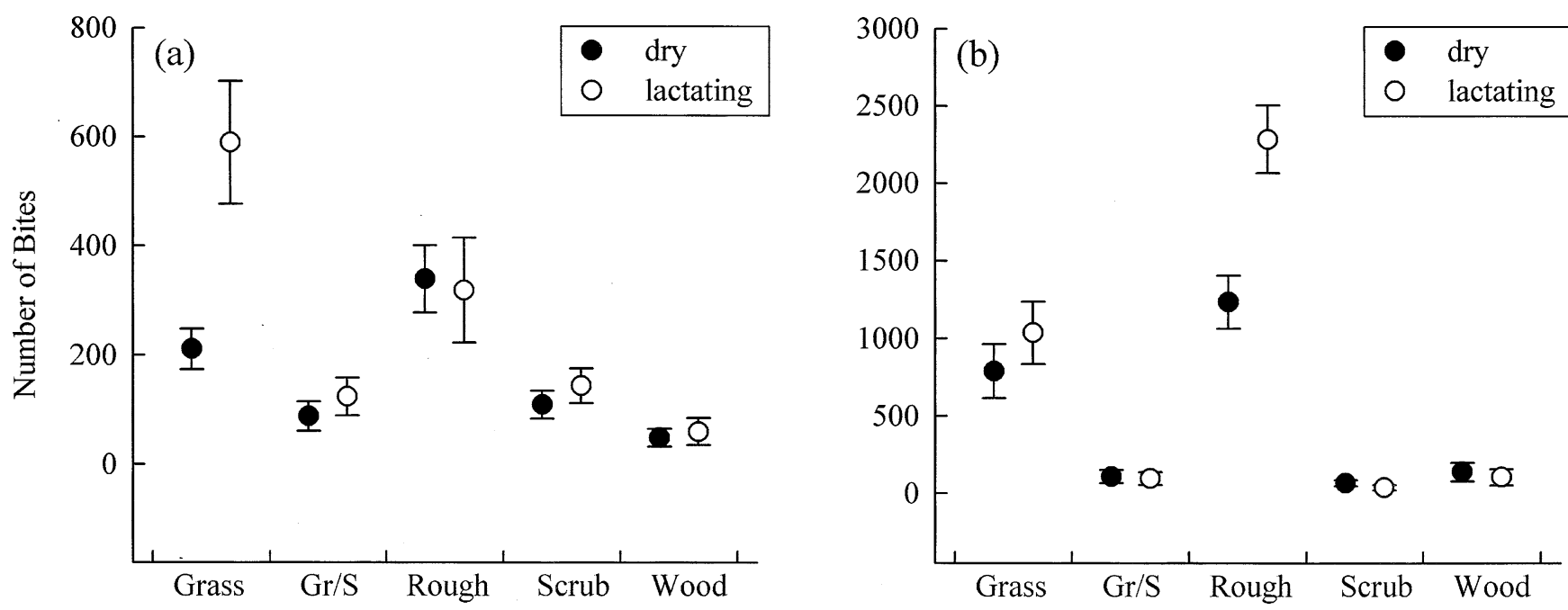

Fig. 2. Mean ( $\pm 1 \mathrm{SE})$ number of bites (per $3 \mathrm{~h}$ ) taken by lactating (open symbols) and dry (solid symbols) animals in distinct habitat types for donkeys (a) and ponies (b). Habitat types: Grass grassy, Gr/S grass/shrub, Rough rough vegetation, Scrub, Wood woodland. Note that the $y$-axes of the two panels have different scales

The number of bites taken per minute grazing was higher in lactating ponies than in dry pony mares (Table 2). There was also a significant effect of the random factor Individual, hence we did not eliminate this factor from the statistical model.

We separately considered the number of bites taken of different food classes. The analyses yielded comparable results for the donkeys and ponies (Table 3). Variation in the number of bites was primarily induced by the factors Lactation State and Food Class, and by the interaction between Food Class and Lactation State (Table 3). In both donkeys and ponies, lactating mares took more bites than dry mares, but this difference was only apparent when they foraged on grasses (Fig. 3). In the case of the ponies there was variation between individuals because we found a significant effect of the random factor Individual.

Grazing behaviour in grassy vegetation and rough vegetation

Both donkeys and ponies spent the most time grazing in grassy vegetation and rough vegetation. These habitat types
Table 3. Results of the ANOVA model examining the effects of the factors Lactation State, Food Class, and Season on the variable "number of bites" taken by donkeys and ponies. Shown are the final models after elimination of non-significant three-way and two-way interactions

\begin{tabular}{|c|c|c|c|c|}
\hline & \multirow[t]{2}{*}{$d f_{1}$} & \multicolumn{3}{|c|}{ Number of bites } \\
\hline & & $d f_{2}$ & $F$ & $P$ \\
\hline \multicolumn{5}{|l|}{ Donkeys } \\
\hline Lactation & 1 & 213 & 11.05 & 0.001 \\
\hline Class & 2 & 213 & 119.65 & $<0.001$ \\
\hline Season & 3 & 213 & 2.08 & 0.104 \\
\hline Class $\times$ Season & 6 & & & \\
\hline Lactation $\times$ Class & 2 & 213 & 9.02 & $<0.001$ \\
\hline Lactation $\times$ Season & 3 & & & \\
\hline Lactation $\times$ Class $\times$ Season & 6 & & & \\
\hline \multicolumn{5}{|l|}{ Ponies } \\
\hline Lactation & 1 & 4.17 & 10.14 & 0.031 \\
\hline Class & 2 & 5.62 & 157.18 & $<0.001$ \\
\hline Season & 3 & 6.98 & 0.58 & 0.648 \\
\hline Class $\times$ Season & 6 & & & \\
\hline Lactation $\times$ Class & 2 & 5.62 & 9.54 & 0.016 \\
\hline Lactation $\times$ Season & 3 & & & \\
\hline Lactation $\times$ Class $\times$ Season & 6 & & & \\
\hline
\end{tabular}




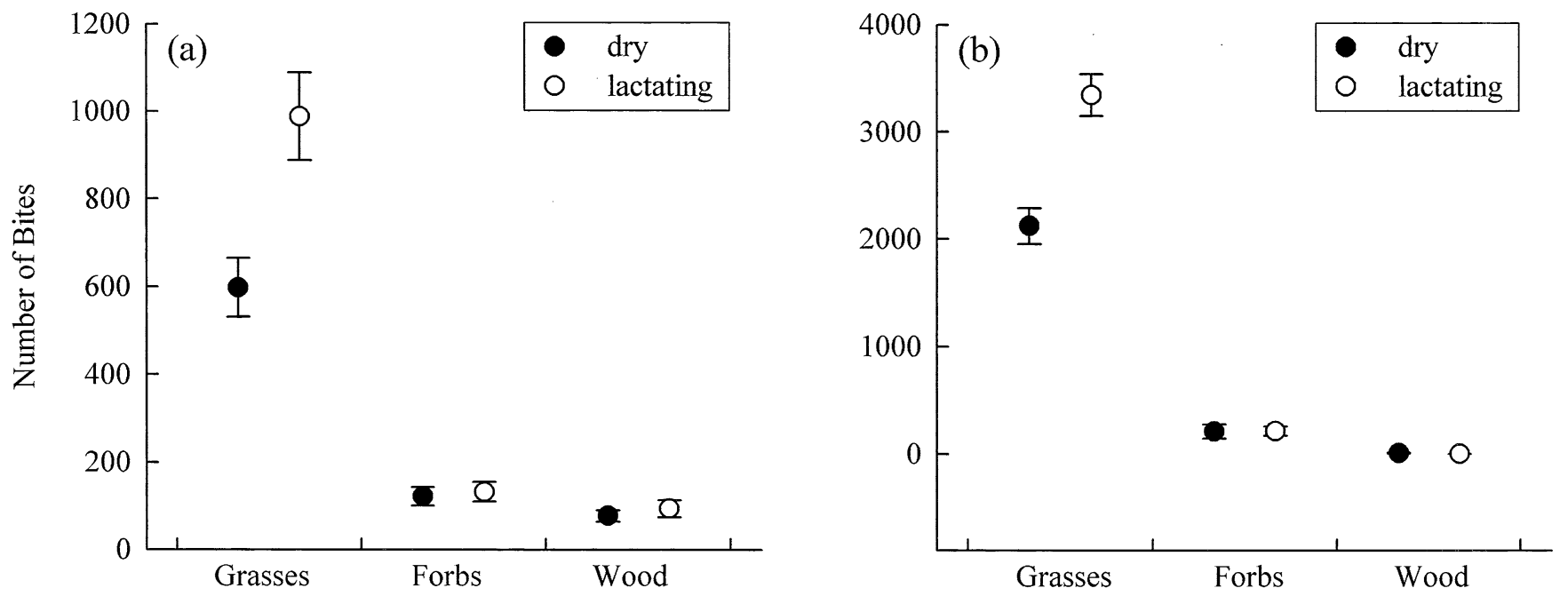

Fig. 3. Mean ( $\pm 1 \mathrm{SE})$ number of bites (per $3 \mathrm{~h}$ ) taken by lactating (open symbols) and dry (solid symbols) animals of distinct forage classes for donkeys (a) and ponies (b). Note that the $y$-axes of the two panels have different scales

Table 4. Results of the ANOVA model examining the effects of the factors Lactation State, Sward Height, and Season on the variables grazing time, number of bites, and bite rate for donkeys and ponies, grazing in grassy habitat and rough vegetation. Shown are the final models after elimination of non-significant three-way and two-way interactions

\begin{tabular}{|c|c|c|c|c|c|c|c|c|c|c|}
\hline & \multirow{2}{*}{$d f_{1}$} & \multicolumn{3}{|c|}{ Grazing time } & \multicolumn{3}{|c|}{ Number of bites } & \multicolumn{3}{|c|}{ Bite rate } \\
\hline & & $d f_{2}$ & $F$ & $P$ & $d f_{2}$ & $F$ & $P$ & $d f_{2}$ & $F$ & $P$ \\
\hline \multicolumn{11}{|l|}{ Donkeys } \\
\hline Lactation & 1 & 369 & 0.85 & 0.356 & 114 & 5.83 & 0.017 & 46.8 & 7.66 & 0.008 \\
\hline Height & 4 & 369 & 16.05 & $<0.001$ & 245 & 12.52 & $<0.001$ & 152 & 3.23 & 0.014 \\
\hline Season & 3 & 369 & 1.30 & 0.274 & 122 & 3.12 & 0.028 & 62.8 & 3.32 & 0.025 \\
\hline Height $\times$ Season & 12 & 369 & 2.83 & 0.001 & & & & & & \\
\hline Lactation $\times$ Height & 4 & & & & 254 & 2.70 & 0.031 & & & \\
\hline Lactation $\times$ Season & 3 & & & & & & & & & \\
\hline Lactation $\times$ Height $\times$ Season & 12 & & & & & & & & & \\
\hline \multicolumn{11}{|l|}{ Ponies } \\
\hline Lactation & 1 & 134 & 3.76 & 0.054 & 124 & 17.55 & $<0.001$ & 9.35 & 10.07 & 0.011 \\
\hline Height & 4 & 213 & 91.63 & $<0.001$ & 203 & 85.92 & $<0.001$ & 136 & 22.96 & $<0.001$ \\
\hline Season & 3 & 140 & 2.52 & 0.061 & 129 & 0.74 & 0.526 & 11.9 & 1.68 & 0.224 \\
\hline Height $\times$ Season & 12 & 219 & 2.17 & 0.014 & & & & & & \\
\hline Lactation $\times$ Height & 4 & & & & 203 & 6.75 & $<0.001$ & & & \\
\hline Lactation $\times$ Season & 3 & & & & & & & & & \\
\hline Lactation $\times$ Height $\times$ Season & 12 & & & & & & & & & \\
\hline
\end{tabular}

also showed the highest variability in sward height. Therefore, we examined whether lactation state had an effect on the sward height utilised by grazing animals in these two habitat types only.

In donkeys, Lactation State and its interactions with other factors had no significant effect on grazing time in grassy vegetation and rough vegetation (Table 4). The number of bites taken by donkeys was significantly influenced by the factors Lactation State, Sward Height, and Season, and by the interaction between Lactation State and Sward Height (Table 4). In grassy vegetation and rough vegetation donkeys took more bites at "hoof height" and this was especially the case for the lactating mares (Fig. 4). Bite rate of donkeys was affected by Lactation State and Sward Height, but not by their interaction (Table 4). In grassy vegetation and rough vegetation lactating mares achieved a higher bite rate than dry mares.

In ponies, there was no detectable effect of Lactation State or of its interactions with other factors on grazing time in grassy vegetation and rough vegetation (Table 4). The number of bites that ponies took in grassy vegetation and rough vegetation was affected by Lactation State, Sward Height, and the interaction between Lactation and Sward Height (Table 4). Lactating mares took more bites than dry mares in closely grazed and hoof-height vegetation, but no differences were apparent in the higher height categories (Fig. 4). Bite rate of ponies was affected by Lactation State and Sward Height, but not by their interaction (Table 4). In grassy vegetation and rough vegetation lactating mares achieved a higher bite rate than dry mares. 

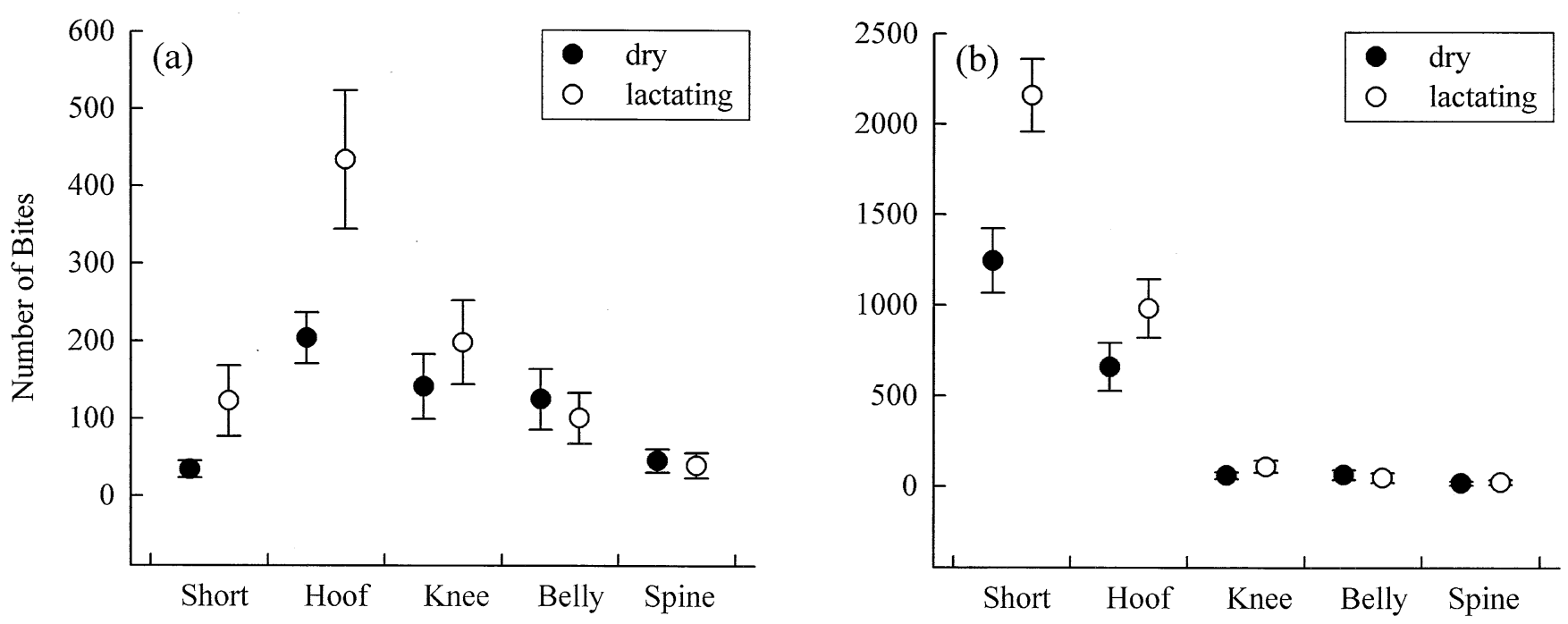

Fig. 4. Mean ( $\pm 1 \mathrm{SE})$ number of bites (per 3 h) taken by lactating (open symbols) and dry (solid symbols) animals of vegetation of distinct height categories in donkeys (a) and ponies (b). Short closely grazed. Note that the $y$-axes of the two panels have different scales

\section{Discussion}

The main objective of the present study was to examine differences in grazing behaviour between lactating and dry free-ranging equids. We expected that the higher nutritional requirements of lactating animals (Pilliner 1999) would induce modifications in their grazing behaviour. Assuming that lactating and non-lactating mares have the same digestive abilities (Rittenhouse 1986), lactating animals should achieve a greater intake of organic matter and/or should select a diet with higher energy and protein content. A greater intake can be obtained by grazing longer, by biting faster, and/or by taking bigger bites. A more nutritive diet can be achieved by selecting the most nutritive plants and plant parts; this selection can be made at the level of the habitat as well as at the level of the individual plant.

The small sizes of the herds that we studied forced us to observe the same small number of individual horses repeatedly, so the results are prone to pseudo replication and may not be applicable to equids in general. The differences that we attribute to lactation state may reflect individual differences induced by some other factor, for example, age in the case of the ponies. However, our interpretation is strengthened by the highly similar results that we obtained for the two species studied, even though they foraged in different areas and differed in several components of their foraging behaviour. Nevertheless, our results should be considered as circumstantial and we encourage further studies based on a larger number of lactating and non-lactating animals.

Our results show that in both donkeys and ponies, lactating animals do not spend more time grazing than nonlactating mares. By contrast, lactating mares take about $50 \%$ more bites and increase their bite rate by 37 and $46 \%$ in donkeys and ponies, respectively. Because we have no data on bite mass, we cannot examine the contribution of possible differences in bite mass to the daily energy intake of lactating and non-lactating mares.

The observed differences between lactating and nonlactating animals in number of bites and bite rate are influenced by other factors. The observed differences between lactating and dry mares vary clearly among habitat types. Lactating donkeys achieve a higher number of bites in grassy vegetation only, while lactating ponies do so in rough vegetation only. Moreover, the increase in number of bites taken by lactating mares in grassy vegetation and rough vegetation is especially pronounced in closely grazed and hoof-high patches. It is known that forage in short patches has a higher digestibility (Van Soest 1982; Wallis de Vries and Daleboudt 1994), and that grazing animals in general select for young growth and reject senescent plant material (McNaughton 1984). Our observations indicate that lactating mares increase the number of bites taken particularly in closely grazed patches. We hypothesize that this behaviour will not allow the lactating mares to obtain a much increased intake of biomass, but rather that they achieve a higher proportion of high quality forage, which is rich in proteins. This would contribute to meeting the much increased protein requirements for lactating mares (NRC 1989).

Horses are considered as grazers that feed predominantly on grasses (Van Dyne et al. 1980; Putman et al.1987; Duncan 1992; Hoffmann et al. 2001; Cosyns et al. 2001; Vulink 2001). Our results indicate that lactating mares select even more strongly for grasses: they increase their number of bites by taking more bites of grasses only, and not of forbs or woody plants (proportion of grasses in the diet, for donkeys: lactating $81.4 \%$ vs dry $75.0 \%$, for ponies: lactating $95.1 \%$ vs dry $90.7 \%$ ).

Results of the few studies that investigated the differences in grazing behaviour between lactating and nonlactating mares showed that lactating mares do not 
significantly increase the time spent grazing (Duncan 1980; Canacoo and Avornyo 1998; Moehlman et al. 1998; Ruckstuhl and Neuhaus 2002). These findings coincide with our results. Only Ruckstuhl and Neuhaus (2002) investigated bite rate in addition to foraging time and concluded that lactating zebra mares have a higher bite rate than nonlactating mares, which is in line with our findings for donkeys and Shetland ponies. Nevertheless, Vulink (2001), who studied one non-reproductive and two reproductive Konik horses that were free ranging in a highly productive area, reported contrasting results. He concluded that the lactating mares foraged significantly longer than the dry mares. Moreover, the number of bites taken of various forage classes was similar between reproductive and nonreproductive horses, indicating an almost identical diet composition and hence a highly similar content of digestible organic matter in their diets. Hence, the higher demands of the lactating Konik mares were met through a higher estimated daily digestible energy intake, achieved by feeding longer (Vulink 2001).

Why did the lactating mares in the present study not increase their grazing time rather than augmenting their bite rate? Free-ranging horses and ponies graze in bouts, separated by periods of non-grazing activity (Tyler 1972; Francis-Smith 1977). When a horse is grazing, oropharyngeal stimuli are enough to induce satiety and to end a meal. However, gastrointestinal stimuli control the duration of satiety (Ralston 1984) and a horse will not start a new feeding bout as long as these stimuli are not given. This physiological constraint, and the necessity to perform other behaviours (resting, travelling, reproductive behaviour, etc.), will result in an upper limit for grazing time. In areas with low forage quantity or quality horses can graze up to $75 \%$ of their total activity time (Putman et al. 1981). Our study was conducted in dune areas with low plant productivity. The dry ponies grazed for $69 \%$ of the time, such that lactating mares could augment their grazing time by only limited amounts. We, therefore, hypothesise that lactating ponies must increase their bite rate to meet their higher energy demands.

The aforementioned hypothesis does not, however, apply to the donkeys in our study. In a study in Ghana, donkeys spent $80 \%$ of their time grazing during the day (Canacoo and Avornyo 1998). In our study, lactating donkeys grazed up to $58 \%$ of their activity time, which seems to be well below the threshold value for grazing time. Why, then, did the lactating donkeys not further increase their grazing time? We hypothesise that the highly synchronous foraging behaviour that is manifest in herds of equids (Boyd and Bandi 2002) acts as a behavioural limit to a further increase in grazing time by the lactating mares.

An additional consideration derives from the optimal foraging theory, which assumes that an animal should maximise its long-term intake rate of energy and other essential nutrients by making a trade-off between gains from energy intake in different patches and costs in time and energy for travel, searching, and food handling (Stephens and Krebs 1986). Assuming that our study animals obtained an optimal balance between costs and gains, we propose that the net proceeds of biting faster are higher than the net gains of an increased grazing time in the lactating animals. Further studies are needed, however, to test these hypotheses.

Acknowledgements The research was conducted in two nature reserves owned by the Flemish government, under supervision of AMINAL (Environment, Nature, Land and Water Administration), section Nature. We thank AMINAL for their permission to conduct the research. I. Lamoot has a grant supplied by FWO Flanders (Foundation of scientific research-Flanders). We thank S. Vanacker and G. Van Spaendonk for creating an Access database, L. De Bruyn for help with statistical analysis, R. Brys for assistance with making figures. We are grateful to E. Cosyns and D. Jacobs for their comments on drafts of the manuscript.

\section{References}

Altmann J (1974) Observational study of behaviour: sampling methods. Behaviour 49:227-267

Boyd L, Bandi N (2002) Reintroduction of takhi, Equus ferus przewalskii, to Hustai National Park, Mongolia: time budget and synchrony of activity pre- and post-release. Appl Anim Behav Sci 78:87102

Canacoo EA, Avornyo FK (1998) Daytime activities of donkeys at range in the coastal savanna of Ghana. Appl Anim Behav Sci 60:229234

Cosyns E, Degezelle T, Demeulenaere E, Hoffmann M (2001) Feeding ecology of Konik horses and donkeys in Belgian coastal dunes and its implications for nature management. Belg J Zool 131:111-118

Doreau M, Boulot S (1989) Recent knowledge on mare milk production: a review. Livest Prod Sci 22:213-235

Duncan P (1980) Time-budgets of Camargue horses II. Time budgets of adult horses and weaned sub-adults. Behaviour 72:26-49

Duncan P (1983) Determinants of the use of habitat by horses in a Mediterranean wetland. J Anim Ecol 52:93-109

Duncan P (1985) Time budgets of Camargue horses III. Environmental influences. Behaviour 92:188-208

Duncan P (1992) Horses and grasses: the nutritional ecology of equids and their impact on the Camargue. (Ecological studies, vol 87) Springer, Berlin Heidelberg New York

Francis-Smith K (1977) Behaviour patterns of horses grazing in paddocks. Appl Anim Ethol 3:292-293

Gibb MJ, Huckle CA, Nuthall R, Rook AJ (1999) The effect of physiological state (lactating or dry) and sward surface height on grazing behaviour and intake by dairy cows. Appl Anim Behav Sci 63:269287

Gordon IJ (1989) Vegetation community selection by ungulates on the Isle of Rhum II. Vegetation community selection. J Appl Ecol 26:5364

Hoffmann M, Cosyns E, Deconinck M, Lamoot I, Zwaenepoel A (2001) Donkey diet in a Flemish coastal dune area in the first year after introduction. In: Houston JA, Edmondson SE, Roony PJ (eds) Coastal dune management. Proceedings of the European symposium coastal dunes of the Atlantic biogeographical region, Southport. Liverpool University Press, Liverpool, pp 95-107

McNaughton SJ (1984) Grazing lawns: animals in herds, plant form and co-evolution. Am Nat 124:863-886

Menard C, Duncan P, Fleurance G, Georges J-Y, Lila M (2002) Comparative foraging and nutrition of horses and cattle in European wetlands. J Appl Ecol 39:120-133

Meteo WVL (2003) http://www.Meteo.koksijde.be

Moehlman PD, Fowler LE, Roe JH (1998) Feral asses (Equus africanus) of Volcano Alcédo, Galapagos: behavioral ecology, spatial distribution and social organization. Appl Anim Behav Sci 60:197210

NRC (National Research Council) (1989) Nutrient requirements of horses, 5th rev edn. National Academy Press, Washington

Neter J, Kutner MH, Nachtsheim CJ, Wasserman W (1996) Applied linear statistical models. McGraw-Hill, Boston 
Parsons AJ, Newman JA, Penning AD, Harvey A, Orr RJ (1994) Diet preference of sheep: effects of recent diet, physiological state and species abundance. J Anim Ecol 63:465-478

Penning PD, Parsons AJ, Orr RJ, Harvey A, Champion RA (1995) Intake and behaviour responses by sheep, in different physiological states, when grazing monocultures of grass or white clover. Appl Anim Behav Sci 45:63-78

Pilliner S (1999) Horse nutrition and feeding. Blackwell, Oxford

Pratt RM, Putman RJ, Ekins JR, Edwards PJ (1986) Use of habitat by free-ranging cattle and ponies in the New Forest, southern England. J Appl Ecol 23:539-557

Putman RJ, Edwards PJ, Ekins JR, Pratt RM (1981) Food and feeding behaviour of cattle and ponies in the New Forest: a study of the interrelationship between the large herbivores of the Forest and their vegetational environment. Report HF3/03/127 to Nature Conservancy Council, Huntingdon

Putman RJ, Pratt RM, Ekins JR, Edwards PJ (1987) Food and feeding behaviour of cattle and ponies in the New Forest, Hampshire. J Appl Ecol 24:369-380

Ralston SL (1984) Controls of feeding in horses. J Anim Sci 59:13541361

Rittenhouse LR (1986) The relative efficiency of rangeland use by ruminants and non-ruminant herbivores. In: Gudmundsson $\mathrm{O}$ (ed)
Grazing research at northern latitudes. Plenum, New York, pp 179191

Ruckstuhl KE, Neuhaus P (2002) Sexual segregation in ungulates: a comparative test of three hypotheses. Biol Rev 77:77-96

Senft RL, Coughenour MB, Bailey DW, Rittenhouse LR, Sala OE, Swift DM (1987) Large herbivore foraging and ecological hierarchies. Bioscience 37:789-799

Stephens DW, Krebs JR (1986) Foraging theory. Princeton University Press, Princeton

Tyler SJ (1972) The behaviour and social organisation of the New Forest ponies. Anim Behav Monogr 5:87-196

Van Dyne GM, Brockington NR, Szocs Z, Duek J, Ribic CA (1980) Large herbivore subsystem. In: Breymeyer AI, Van Dyne GM (eds) Grasslands, systems analysis and man. Cambridge University Press, Cambridge, pp 269-537

Van Soest PJ (1982) Nutritional ecology of the ruminant. O and B Books, Corvallis

Vulink T (2001) Optimal diet choice of free-ranging horses in vegetation of Phragmites australis and tall herbs: a causal analysis. In: Vulink T (ed) Hungry herds. Management of temperate lowland wetlands by grazing. Van Zee tot Land 66, Lelystad, pp 65-85

Wallis de Vries MF, Daleboudt C (1994) Foraging strategies of cattle in patchy grassland. Oecologia 100:98-106 